Bustanul Arifin, Komang Audina Permana Putri| Indonesian Government Strategies On Obtaining Crude Palm Oil (CPO) Market Access To European Union Countries Over The EU Parliament Resolution On Palm Oil And

Deforestation Of Rainforest

Article

\title{
Indonesian Government Strategies On Obtaining Crude Palm Oil (CPO) Market Access To European Union Countries Over The EU Parliament Resolution On Palm Oil And Deforestation Of Rainforest
}

Bustanul Arifin ${ }^{1}$, Komang Audina Permana Putri ${ }^{2}$

${ }^{I}$ Supernova Education Center, Jawa Barat, Indonesia

${ }^{2}$ Supernova Education Center, Jawa Barat, Indonesia

\section{SUBMISSION TRACK}

$$
\begin{array}{ll}
\text { Recieved } & : \text { 20 June } 2019 \\
\text { Final Revision } & : \text { 07 August } 2019 \\
\text { Available Online } & : \text { 30 November } 2019
\end{array}
$$

KEYWORD

Indonesian Diplomacy, Abu Sayyaf, Multi-Track

Diplomacy, Total Diplomacy

\section{KATA KUNCI}

Diplomasi Indonesia, Abu Sayyaf, Diplomasi

Multi track, Diplomasi Total

\section{CORRESSPONDENCE}

E-mail : bustanul2arifin@gmail.com

audinapermana143@gmail.com
A B S T R A C T

Indonesia is the largest producer of palm oil in the world. With Malaysia, palm oil production could account for about eighty percent of global production. Meanwhile, European Union is the third largest CPO export destination for Indonesia after India and China. However, the EU proposed a European Union resolution initiative on palm oil and deforestation of rainforest, which finally passed with the major votes from EU members of Parliament in April 2017. The key point on EU resolution reveals that EU will ban palm oil use for biofuels production by 2020. The purpose of this research is to analyze the Indonesian government's diplomatic efforts to respond and negotiate with EU regarding the issue. To analyze the diplomatic efforts, the researcher uses qualitative methods presented through data collection from sources such as books, journals, press releases and official reports from institutions. To support the research, the researcher also uses primary data through interview with one of the representative of the Ministry of Foreign Affairs of the Republic. This research finds that the government of Indonesian finally combined several soft diplomatic strategies to face EU through Indonesian government efforts; by making a joint of creation of objection letter, by responding over the issue through CPOPC role, by campaigning the fair trade of CPO products through bilateral approaches by Indonesian Minister of Foreign Affairs, and lastly by negotiating with EU through Indonesia-EU CEPA.

A B S T R A K

Indonesia merupakan produsen kelapa sawit terbesar di dunia. Bersama Malaysia, produksi kelapa sawit dapat mencakup sekitar delapan puluh persen dari total produksi global. Sementara itu, Uni Eropa merupakan tujuan ekspor CPO terbesar ke-3 bagi Indonesia setelah India dan China. Terlebih lagi semenjak Uni Eropa mengajukan inisiatif resolusi Uni Eropa terhadap kelapa sawit dan deforestasi hutan tropis yang akhirnya pada tahun 2017 lolos dengan hasil voting terbanyak yang mendukung Resolusi tersebut dari anggota dari EU Parlemen yang menyatakan akan melarang penggunakan kelapa sawit untuk produksi bahan bakar bio pada tahun 2020. Untuk menganalisis usaha diplomasi tersebut, penulis akan menggunakan metode kualitatif yang dipaparkan melalui kumpulan sumber-sumber data seperti buku, jurnal, press beberapa strategi diplomatik 
Bustanul Arifin, Komang Audina Permana Putri| Indonesian Government Strategies On Obtaining Crude Palm Oil (CPO) Market Access To European Union Countries Over The EU Parliament Resolution On Palm Oil And

Deforestation Of Rainforest

lunak untuk menghadapi UE melalui beberapa upaya pemerintah Indonesia seperti; membuat surat penolakan bersama dari negara-negara pengekspor $\mathrm{CPO}$, menanggapi masalah ini melalui peran CPOPC, mengkampanyekan perdagangan adil produk CPO melalui pendekatan bilateral oleh Menteri Luar Negeri Indonesia, dan terakhir dengan bernegosiasi dengan UE melalui Indonesia-EU CEPA.

\section{Introduction}

Indonesia considered as a world's largest producer country of palm oil and the industry has given Indonesia's economy's most valuable on the agricultural export sector for the past decade. ${ }^{1}$ Palm oil is a plantation that has experienced considerable growth in production compared to other plantation crops in Indonesia. In fact, since 2006, Indonesia becomes the largest country to produce palm oil and despites of that fact; world palm oil production is currently dominated by Indonesia and Malaysia. ${ }^{2}$ According to FAO on Palm Oil Production Records, the growth of Indonesia production on palm oil is very significantly since the early 2000 . The continuing growth even occurred since the year of 1989. Moreover in 2009 until 2010, total palm oil production was estimated at 45.1 million tones, with Indonesia and Malaysia accounts for more than 85 percent of the world total. ${ }^{3}$

World palm oil consumption tends to increase by 9.66 percent per year while world palm oil production growth is only

\footnotetext{
${ }^{1}$ Kurnia, Jundika C, Ssachin V. Jangam, and others. (2016). "Advances in biofuel production from oil palm and palm oil processing wastes". Biofuel Research Journal. Retrieved from http://www.biofueljournal.com/article_11937_b39e 801349deb76be4a15f0a1fd93e3c.pdf

${ }^{2}$ FAO (Food, Agriculture Organization) Report. Global Resources Assessment 2010. Retrieved from www.fao.org

${ }^{3}$ Ibid.
}

7.94 percent per year. ${ }^{4}$ Because of the increase of demand, Indonesian CPO production and export has also increased. Indonesia CPO production significantly increased since in the year of 2000 and it continues to grow until in 2016 it declines around 3 per cent. Then, seventy per cent from the total of production is exported in 2016. ${ }^{5}$ It makes palm oil commodities able to provide very large contribution by the foreign exchange for the Indonesian economy.

One of the largest country destinations for Indonesian palm oil export is European Union (EU). According to Eurostat 2010, palm oil commodity is the biggest export product from Indonesia to EU. ${ }^{6}$ Palm oil can be used as a feedstock for biodiesel production, especially with the EU has a target to increase biofuels uses. EU big concern on sustainable energy brings to the EU's target of sourcing 10 percent transports from biofuels. Since then, EU biodiesel becomes the main biofuels used for transport, which account 79 per cent of total use of biofuels in 2015. From that

\footnotetext{
4 Indonesian Ministry of Trade Report. (2013). Analysis of Indonesia's strategies to Increase Crude Palm Oil Production. Retrieved from http://bppp.kemendag.go.id/

${ }^{5}$ Katadata Research. (2017). " Berapa Produksi dan Ekpor Minyak Sawit Indonesia?". Retrieved from https://databoks.katadata.co.id

${ }^{6}$ EEAS (European External Action Services). Trade Flows Indonesia and EU. Retrieved from http://eeas.europa.eu/delegations/indonesia/eu_indo nesia/trade_relation/trade_flows/index_en.htm
} 
Bustanul Arifin, Komang Audina Permana Putri| Indonesian Government Strategies On

Obtaining Crude Palm Oil (CPO) Market Access To European Union

Countries Over The EU Parliament Resolution On Palm Oil And

Deforestation Of Rainforest

case, total share of palm oil used as biodiesel feedstock in EU account 13 per cent. $^{7}$ This makes Indonesian palm oil export also significant for energy sector in EU.

Besides of the trade relations between Indonesia and European countries that seems mutually benefits according to EEAS data of trade flows between EU and Indonesia, however there is still a significant challenge faced by the Indonesian CPO industries, which is the EU Parliament Resolution on eliminating palm oil for biofuels production by 2020 . The EU Parliament Resolution is an initiation report from MEPs (Members of EU Parliament) regarding the uses of palm oil that assumed it could give the impact toward deforestation in rainforest.

Even though the resolution is not binding policy or has no legal effect, however it can invites the EU Commission (EC) to take further action regarding the issue. While EU Parliament had passed the resolution, EU Commission also prepare for the establishment of RED II Proposal. The Renewable Energy Directive (EU RED II) has been determined as binding policy to continue EU 2020 renewable energy target that also stated to decrease biodiesel cooking oil based. This directive is a legally binding EU legislative product that will continue the renewable energy program after 2020. That is why it is significant for Indonesian government to respond the issue to keep spreading positive campaign for Indonesian CPO products.

The European Parliament Resolutions on palm oil and deforestation of rainforest underlining that palm oil, as one of a feedstock for biodiesel production, which may become the causes of

\footnotetext{
7 European Commission Report. (2017). "Renewable Energy Progress Report". Retrieved from

https://ec.europa.eu/transparency/regdoc/rep/1/2017/ EN/COM-2017-57-F1-EN-MAIN-

PART-1.PDF
}

Indonesian deforestation on rainforest. ${ }^{8}$ In addition, it also stated that fires in Indonesia are typically the result of the clearing of land for palm oil plantations and other agricultural uses; whereas 52 per cent of fires in Indonesia in 2015 occurred in carbon-rich peat lands, turning the country into one of the largest contributors to global warming on Earth. ${ }^{9}$ The resolution also recommends to the single certification system for sustainable palm oil.

However, since the EU Parliament had passed the resolution, Indonesian government responded with the objection and believes that it was a "discrimination and unfair action”. Indonesian government refers toward the EU study 2013 that shows palm oil production only accounts for 2.3 percent of deforestation, while livestock grazing contributes 24.26 percent and soybean farming accounts for 5.4 percent. $^{10}$ Indonesian government also underlined for the unfair has seen because the Resolution promotes other vegetable oil, which also able to contribute on deforestation.

This issue brought to the Fourth Ministerial Meeting Council of Palm Oil Producing Countries (CPOPC) that held in Jakarta on 11 April 2017. ${ }^{11}$ There are two significant recommendation from this meeting, which are the strengthening the cooperation between Malaysian and Indonesia as the palm oil major producing countries on addressing palm oil trade challenges including the EU Resolution and also the ensuring the certification standard

\footnotetext{
${ }^{8}$ European Parliament Resolution. (4 April 2017). Texts adopted, P8_TA(2017)0098.

${ }^{9}$ Ibid

${ }^{10}$ EU Study (2013). "Impact of EU Consumption on Deforestation”. European Commision Technical Report- 063. Retrieved from http://ec.europa.eu/environment/forests/pdf/1.\%20R eport\%20analysis\%20of\%20impact.pdf

${ }^{11}$ Indonesian Ministry of Foreign Affairs (April 2017). Joint Communiqué: Fourth Ministerial Meeting Council of Palm Oil Production Country. Retrieved from www.kemlu.go.id
} 
Bustanul Arifin, Komang Audina Permana Putri| Indonesian Government Strategies On

Obtaining Crude Palm Oil (CPO) Market Access To European Union

Countries Over The EU Parliament Resolution On Palm Oil And

Deforestation Of Rainforest

on sustainable palm oil through the Indonesia Sustainable Palm Oil (ISPO) and Malaysia Sustainable Palm Oil (MSPO). ${ }^{12}$

Even before that meeting, Indonesia also joint on the contribution for making the objection letter even before the law passed in April 2017. The letter was made by several ambassadors from palm oil producing countries in Brussels and sent it to the European Commission on 27 March $2017 .{ }^{13}$ The letter examined those producing palm oil countries data on how does the palm oil had gave the economic boosting and the current condition on smallholder that highly depend on the palm oil industries, including Indonesia.

\section{Research Method}

This research will use the Qualitative research method. The writer also uses Library Research method in order to analyze historical records, or theory that available. The observation will examine the basic of international relations theory on Economic Diplomacy and International Trade. Many main data analysis in this research will be from 2015 to 2017.

\section{a. Economic Diplomacy}

The concept for economic diplomacy according to Peter A.G., Bergeijk, and Okano Heijmans ${ }^{14}$ is to define on how the process of negotiations able to proceed in different environments such as regional, bilateral or multilateral economic. In this case of study, the writer will use the bilateral and multilateral diplomacy to be focused on. By looking at the conceptual framework to study diplomatic process, the writers use the framework by Peter A.G., Bergeijk, and Okano Heijmans study to

\footnotetext{
${ }^{12}$ Ibid

${ }^{13}$ Letter from Palm Oil Producing Countries (27 March 2017). Retrieved from www.fern.org

${ }^{14}$ Melissen, J., Okano-Heijmans, M., and Bergeijk, P.A.G. (2011). "Economic Diplomacy: Economic and Political Perspectives". Leidon: Boston.
}

define the context in which economic diplomacy is exercised (see figure1).

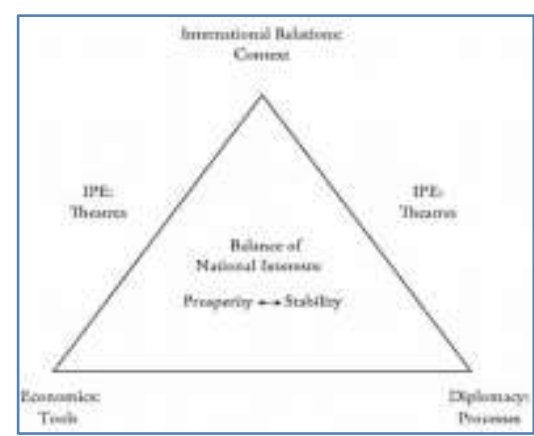

Figure 1. The Analytical Framework for Study on Economic Diplomacy: Conceptual Economic Diplomacy $^{15}$

The economic tools by it means from the context is generally results of the government focus on economic problems that could be seen as an object of why government should do economic diplomacy. ${ }^{16}$ The structure in international relations that facilitates the theatres that means negotiating is could be seen as an International Institutions or Organization such as ASEAN or European Union. ${ }^{17}$ And the last is a diplomacy process, which it explains on how does the diplomacy processes are practiced.

To seeing each angle or the concept more easier, the authors also help with putting different questions which considers economic tools as the "what", diplomacy process is "how" and theatre as "where". Those are strategy used in economic diplomacy for states pursue national interest as the comprising for the economic prosperity and political stability. ${ }^{18}$ From this context, the economic tools can be related to the Indonesian government

\footnotetext{
${ }^{15}$ Ibid.

${ }^{16}$ Melissen, J., Okano-Heijmans, M., and Bergeijk, P.A.G. (2011). "Economic Diplomacy: Economic and Political Perspectives". Leidon: Boston.

${ }^{17}$ Melissen, J., Okano-Heijmans, M., and Bergeijk, P.A.G. (2011). "Economic Diplomacy: Economic and Political Perspectives". Leidon: Boston. 18 Ibid.
} 
Bustanul Arifin, Komang Audina Permana Putri| Indonesian Government Strategies On

Obtaining Crude Palm Oil (CPO) Market Access To European Union

Countries Over The EU Parliament Resolution On Palm Oil And

Deforestation Of Rainforest

concerns on the issue of EU's parliament resolution that restrict the chances of Indonesian palm oil products export to enter European countries.

Because of the broad range of economic activities, Peter A.G., Bergeijk, and Okano Heijmans divided into five clusters in economic diplomacy, which in this research, the writer will focus on the second and fifth cluster on trade diplomacy (see figure 2). Each cluster of economic diplomacy involves a wide variety of activities and expression. Moreover, the author also stated that countries are more successful in economic diplomacy if they increase the numbers of activities; conceive of new ways to conduct economic diplomacy or to terminate activities that have proven unsuccessful. ${ }^{19}$

\begin{tabular}{|c|c|c|c|c|}
\hline $\begin{array}{l}\text { Commencial } \\
\text { diplemacy }\end{array}$ & Trade diplomacy & $\begin{array}{l}\text { Financial } \\
\text { diplomacy }\end{array}$ & Inducements & Sanctions \\
\hline $\begin{array}{l}\text { trade promotion } \\
\text { investment } \\
\text { promotion }\end{array}$ & $\begin{array}{l}\text { bilateral: } \\
\text { FTAs, EPAs } \\
\text { multilateral: WTO }\end{array}$ & $\begin{array}{l}\text { currency swap } \\
\text { agreements } \\
\text { Exchange-rate } \\
\text { policy }\end{array}$ & $\begin{array}{l}\text { bilateral aid: } \\
\text { grants, loans } \\
\text { debe relief }\end{array}$ & $\begin{array}{l}\text { cmbargo } \\
\text { (exports; state) } \\
\text { boycott } \\
\text { (imports; } \\
\text { individuals) }\end{array}$ \\
\hline business advocacy & $\begin{array}{l}\text { (anti-dumping) } \\
\text { tariffs }\end{array}$ & $\begin{array}{l}\text { buying/selling of } \\
\text { government bonds }\end{array}$ & humanitarian aid & aid suspension \\
\hline $\begin{array}{l}\text { tourism promotion } \\
\text { promotion of } \\
\text { socially repponsible } \\
\text { investing }\end{array}$ & $\begin{array}{l}\text { export or import } \\
\text { licenses } \\
\text { import or export } \\
\text { quotas, trade and } \\
\text { investment } \\
\text { barriess }\end{array}$ & $\begin{array}{l}\text { freering assets } \\
\text { withholding duo } \\
\text { or payments }\end{array}$ & $\begin{array}{l}\text { granting access to } \\
\text { technology } \\
\text { granting } \\
\text { membership of } \\
\text { international } \\
\text { otganization }\end{array}$ & $\begin{array}{l}\text { capital controls } \\
\text { blacklist }\end{array}$ \\
\hline
\end{tabular}

Figure 2. The Clusters on Economic Diplomacy: Conceptual Economic Diplomacy by Melissen, Okano-Heijmans, \& Bergeijk ${ }^{20}$

On the second cluster, the writer allege to the case study that because of the IEUCEPA that Indonesia and EU has, this agreement become the economic tools for Indonesia to negotiate the palm oil issue with EU. This could be seen on the second cluster from the trade diplomacy focus. On the other hand, on the fifth cluster, this can be conceived as EU behavior while they ban the palm oil using certain reasons to sanction the products and apparently blacklist the uses of the products.

\footnotetext{
${ }^{19}$ Ibid.

${ }^{20}$ Ibid.
}

Both clusters are seems connected, which it also explained in the theory that the multitude of activities within the different economic diplomacy strands from interdependence system, which means these activities are connected by linkage that occur when the way of which one of activity is performed affects the cost or effectiveness of other activities. Both clusters $\left(2^{\text {nd }}\right.$ and $\left.5^{\text {th }}\right)$ that explained above could be as an example to be studied in this research.

Looking through the same concept by Nicholas Bayne and Stephen Woolcock on theory of the new economic diplomacy, the author also underline that economic diplomacy has the assumption that official diplomatic activities are focused on increasing exports, attracting investment and participating in international economic organization activities. ${ }^{21}$ Nicholas Bayne and Stephen Woolcock also define new economic diplomacy as a series of activities (both on methods and processes for international decision-making) related to cross-border economic activity (exports, imports, investments, loans, assistance, migration) conducted by state and non-state in the world. He examines that economic diplomacy is actually defined as "the process of international economic decisionmaking". 22

It means that the focus of the economic diplomacy study is on how states conduct their external relations by making decisions domestically that include the external negotiation. The processes of those interactions studied with the aim to promote international trade. In addition, according to Nicholas Bayne and Stephen Woolcock, many activities of non-state actors also considered relevant in this

\footnotetext{
${ }^{21}$ Bayne N., Woolcock S. (editors). 2010. 2nd edition. The New Economic Diplomacy. Decisionmaking and Negotiation in International Economic Relations. Surey (UK): Ashgate Publishing Limited, ISBN 978-0-7456-7048-3, p. 391

${ }^{22}$ Ibid.
} 
Bustanul Arifin, Komang Audina Permana Putri| Indonesian Government Strategies On

Obtaining Crude Palm Oil (CPO) Market Access To European Union

Countries Over The EU Parliament Resolution On Palm Oil And

Deforestation Of Rainforest

diplomacy. By improving the function of markets, the study of economic diplomacy also face great challenge such as trade barriers.

\section{b. International Trade}

In order to provide deeper knowledge on international trade behavior, the writer use the concept from Joseph E. Stiglitz study. On his book of Making Globalization Work, the author underlined the concept of international trade which seeing the making fair trade as the main arguments. He believes that despites of the success of globalization in which rising the number of international trade activities, there are still the lack of the global trade system that include the fair in trade activities. ${ }^{23}$ In this research, the challenge faced by Indonesia government that consider the EU policy as a trade barriers becomes a case study based on Joseph E. Stiglitz believes on the current global trade fairness challenge.

Free trade should be seeing as the activity of trade for goods or services flows unhindered by government-imposed restrictions and interventions, it means free trade is technically opposes all such intervention, including trade barriers. The existence of the international trade barriers such as legal factors continue to present challenges for business communities that decided to participate in the World Trade Organization (WTO) in order to promote trade liberalization initiative to the state level or regional level.

On the other hand, international trade is often limited by various tax/duty imposed by the state but also include the non-tariff regulation on import goods. Theoretically all of these barriers are opposed by free trade. Non-tariff barriers is a form of restrictive trade where barriers to trade are set up and take a form other than a tariff, such as application of high standards of

\footnotetext{
${ }^{23}$ Stiglitz, J.E. (2006). Making Globalization Work: First Edition. New York: USA. P.90
}

certain imported goods. ${ }^{24}$ Seeing with the EU Parliament Resolution that considered by Indonesian government as unnecessary barriers, the concept of trade barriers is unavoidable issue to examine in this research.

Meanwhile, according to international trade study from Joseph E. Stiglitz, global trade challenges faced majorly by developing countries. Trade liberalization challenge the more toward developing countries, including with technical and non-tariff barriers. On his book of making trade fair in global trade challenges, despites of the reduction on tariffs barriers are able to come down, non-tariff barriers does not eliminate protectionist sentiment or politics within the global trade. Advance industrial countries have been particularly imposing the non-tariff barriers sentiment, which take number of forms and make challenge within the global trade fair. ${ }^{25}$

The behaviors of advance or developed countries by using the non-tariff barriers is deeply examined by Joseph E. Stiglitz book on making globalization work. On this case, it could be related with the behavior of EU restricted ability and restrain the export from developing countries through the EU Parliament initiation report or EU Resolution. According to Joseph E. Stiglitz, global trading system has seen loaded against the poorer countries through the trade barriers, which seems the highest. The author also mentioned that there are significant parts of advance industrialized countries' trade policy which able to materially retrain the development of poorer countries and pressure of the developing countries participate in international trade. ${ }^{26}$

\footnotetext{
${ }^{24}$ Wijatno, S and Gunadi, A. (2014). "Free Trade: in International Trade Law Perspective”. PT. Grasindo; Jakarta, p. 35.

${ }^{25}$ Stiglitz, J.E. (2006). Making Globalization Work: First Edition. New York: USA. P.90

${ }^{26}$ Ibid.
} 
Bustanul Arifin, Komang Audina Permana Putri| Indonesian Government Strategies On

Obtaining Crude Palm Oil (CPO) Market Access To European Union

Countries Over The EU Parliament Resolution On Palm Oil And

Deforestation Of Rainforest

In light with the phenomenon of international trade, which challenges more toward the developing countries, the international agreement also often becomes a common tool for negotiation processes. ${ }^{27}$ Indonesia itself has been a contracting party or subject to many trade agreements, including an agreement made with European Union. Through the negotiation in Indonesia EU - Corporation Economic Partnership Agreement (IEU-CEPA), this research will further elaborate the role of this agreement is significant for Indonesia to negotiate the issue regarding the EU's Parliament Resolution.

\section{Result and Discussion \\ European Union Parliament Resolution on Palm Oil and Deforestation of Rainforest}

EU Parliament Resolution is not type of EU legal framework that has legal effect; meanwhile the EU Resolution is an initiation document from members of EU Parliament to set out future work foreseen in a specific policy area. Because of the uses for this document only set up political commitments, therefore this initiation is not binding and not intends to have legal effects. $^{28}$ This resolution initiates by EU Parliament or usually calls as MEPs (Member of European Parliament), however MEPs can invite EU Commission to take further action toward the document or resolution. ${ }^{29}$ It means that even though the resolution is not binding legal framework, the EU Commission can use the report or resolution document into the legislative products consideration.

\footnotetext{
${ }^{27}$ Wijatno, S and Gunadi, A. (2014). "Free Trade: in International Trade Law Perspective”. PT. Grasindo; Jakarta, p. 35.

${ }^{28}$ European Council of the European Union. "Council Conclusions and Resolutions". Retrieved from www.consilium.europa.eu

${ }^{29}$ Ibid.
}

In other words, only EU Commission that consists by 28 representatives from each member country are able to propose legal regulation. The EU resolution could become the consideration for EU Commission on EU legal framework or policy for instance, the EU Directives to regulate biodiesel or EU RED II (Renewable Energy Directive). The resolution was started by MEPs proposed a draft in 2016. The references letter code for the resolution is 2016/2222(INI) Palm Oil and Deforestation of Rainforest, which INI refers to initiative. ${ }^{30}$

According to the report of EU resolution on palm oil and deforestation of rainforests, the EU committees that give the opinions are from EU Committee on Development, International Trade, and Agricultural and Rural Development. Moreover, with the committee who responsible is the EU Committee on Environment, Public Health and Food Safety (ENVI).

It was begin with the draft report and continue to several debates and vote in Parliament. The EU initiative report is apparently took voting results in April 2017, which reveals major MEPs approved or was in favor with resolution accounts 640 MEPs. In addition, 18 MEPs were against with the resolution and 28 MEPs abstained from voting. ${ }^{31}$ By the end of the voting, the resolution will bring to $\mathrm{EU}$ Commission to respond as the consideration of EU legal framework.

Moreover, the resolution also gets the supports from several European NGOs, which also contribute on voting on April 2017. These NGOs including Friends of the Earth Europe, Global Witness, Fern, Zero, Transport and Environment and etc.

\footnotetext{
${ }^{30}$ European Parliament. Procedure File: 2016/2222(INI). Retrieved from www.europarl.europa.eu

${ }^{31}$ Sundram, K., (2017). "The EU's Palm Oil and Deforestation Resolution". Retrieved from www.palmoilhealth.org
} 
Bustanul Arifin, Komang Audina Permana Putri| Indonesian Government Strategies On

Obtaining Crude Palm Oil (CPO) Market Access To European Union

Countries Over The EU Parliament Resolution On Palm Oil And

Deforestation Of Rainforest

According from vote in favor letter from these NGOs, they agree to call for the EU Commission to take further and forceful action toward the case. On the last paragraph of the letter, they expressed their statement that they agreed for MEPs to phase out vegetable oil including palm oil for biofuels production. ${ }^{32}$

The EU Parliament Resolution on Palm Oil and Deforestation consists of 27 observations, 25 general considerations and 54 recommendations statements or paragraphs. ${ }^{33}$ The resolution is focus on the implication of palm oil as the uses of palm oil products arise as the biofuels trends, however it also consider on many drivers of global deforestation including several agricultural commodities such as maize, soy, beef and palm oil. However due to the increasing demand and causes of palm oil for deforestation, which estimated also would effects vividly, EU action to halt deforestation is to cut the uses of palm oil products on biofuels production.

The resolution calls the EU Commission to honor International commitments that EU has, such as COP21, the UN Forum on Forests, the UN Convention on Biological Biodiversity, the New Work Declaration on Forests and also SDGs to terminate deforestation by $2020 . .^{34}$ It means that the resolution refers to those commitments that EU has taken in order to have further action toward environment issue. The resolution also stresses on EU Commission to work closely with other significant consumers including China and India and producing countries to study on

32 Statement Letter from NGOs to European Parliament. (April 2017). Undersigned Organization Letter. Retrieved from www.fern.org

33 R. Vasuthewan. (2017). "EU Parliament's Resolution to Ban Palm Oil by 2020?”. ISCC Report. Retrieved from www.iscc-system.org

${ }^{34}$ European Parliament Resolution. (4 April 2017). Texts adopted, P8_TA(2017)0098. common solution regarding the impact of palm oil on forestry degradation. ${ }^{35}$

Moreover, the resolution is not only focus on Indonesia and Malaysia as the major producer countries, however EU also concerns on other Asian, African and Latin America countries who produce palm oil that can be related with the driver of deforestation caused by palm oil cultivation. It stated on observation statement paragraph 14. However, because of Indonesia and Malaysia increasing palm oil production since 1970 s estimated to hold around 90 percent from palm oil global production, EU concentrate more toward the position of Indonesia and Malaysia within the resolution. ${ }^{36}$ Therefore, how important the position of Indonesia for EU palm oil trade would be explained on further in below paragraphs especially o what is on the EU Parliament Resolution. Within this resolution, it recalls EU and Indonesia position as the trading states on palm oil commodity. It stated on general consideration paragraph 8 and 13 that recalls EU is a major importer of products, which resulting deforestation and around 7 million tones palm oil import per year, it makes EU as the second largest global importer. On the other hand, general consideration paragraph 12 stated that Indonesia becomes the third highest polluter in the world, which include suffers from decreasing biodiversity, several endangered species. ${ }^{37}$

In addition, on the EU resolution in the beginning of paragraph on general consideration, MEPs clearly mention that in 2014, EU responsible for 60 percent import palm oil uses and from that total, $46 \%$ was

\footnotetext{
${ }^{35}$ Ibid.

${ }^{36}$ Statement Letter from NGOs to European Parliament. (April 2017). Undersigned Organization Letter. Retrieved from www.fern.org

37 Statement Letter from NGOs to European Parliament. (April 2017). Undersigned Organization Letter. Retrieved from www.fern.org
} 
Bustanul Arifin, Komang Audina Permana Putri| Indonesian Government Strategies On

Obtaining Crude Palm Oil (CPO) Market Access To European Union

Countries Over The EU Parliament Resolution On Palm Oil And

Deforestation Of Rainforest

used in energy sector such as biodiesel production. ${ }^{38}$ It means, the issue brought by EU to the phase out palm oil uses for biodiesel is due to the high rank of EU palm oil consumption for biodiesel production. The Government of Indonesia (GOI) objection toward some of EU paragraphs, the writer divides into four points which are first, the uncertain of data for palm oil contribution on global deforestation, the promotion on rapeseed or sunflower oil, single certification and Social and Human Rights Violation in Palm Oil Industries.

Then we can underline several points in EU Resolution, which consisted by of 27 observations, 25 general considerations and 54 recommendations statements. The writer summarized three main initiative that propose by the Parliament, which are (i) the resolution underlines the ban of palm oil uses for biofuels production that related with the issue of deforestation current condition, (ii) social and human rights issue, and (iii) the calls for EU Commission to have single certification. However, it has brought to the objection by Indonesian government toward the initiation. The major reason for the objection is because EU resolution stated to promote the use of rape or sunflower oil, which according to study it also brought the significant impacts on GHG emissions, and the type of those crop have less production regard with total land used. In addition, having a single certification might oppose the existence of ISPO and MSPO, which has been created for the sustainable product certification.

\section{Indonesia Crude Palm Oil Trade to European Countries}

The oil palm commodity has a relevant role in the Indonesian economy.

\footnotetext{
${ }^{38}$ European Parliament Resolution. (4 April 2017). Texts adopted, P8_TA(2017)0098.
}

The palm oil industry becomes the largest foreign exchange earner after oil and gas commodities. The development of palm oil consumption shows an increasing trend in the world. It makes Indonesia's palm oil exports seem to broaden their market, and the trends shows that the industry is currently not only focus on the demand in Asia or Unites States market but also in European market. ${ }^{39}$

The EU becomes the main market for Indonesia's CPO exports since 2008 (table 2). And in 2016, EU becomes Indonesia third largest palm oil export destination after India and China. ${ }^{40}$ This issue of high demand in EU is not only due to EU high consumption on vegetable oil for food but also development on biofuels production. In this case, EU uses palm oil for biodiesel production. Nevertheless, Indonesia Palm oil export in EU has increase significantly since the commodity has more function on biofuels production. ${ }^{41}$ Utilizing CPO for biodiesel production encourages EU demand on palm oil significantly. This issue noted in EU Resolution on Palm Oil and Deforestation of Rainforest. In addition, EU is one of the main alternative markets for Indonesia's palm oil export, especially for several European countries including Netherland, Italy and Spain.

The EU as an important market in Indonesia since the export volume has highest peak in several European countries, which in 2009 Indonesia's CPO exports to the EU countries amounted to 3.6 million tons. IPOA also noted that Indonesia's CPO exports to EU countries increased by 2.6

\footnotetext{
${ }^{39}$ Wdoido, T. and Widyaningtyas, D. (n.d).

"Analisis Pangsa Pasar dan Daya Saing CPO

Indonesia di Uni Eropa”. Univeristas Gadjah Mada Journal

${ }^{40}$ Katadata Research. (2016). "Volume Ekspor

Minyak Sawit ke 10 Negar Tujuan Utama".

Retrieved from www.databoks.katadata.co.id

${ }^{41}$ European Parliament Resolution. (4 April 2017).

Texts adopted, P8_TA(2017)0098.
} 
Bustanul Arifin, Komang Audina Permana Putri| Indonesian Government Strategies On

Obtaining Crude Palm Oil (CPO) Market Access To European Union

Countries Over The EU Parliament Resolution On Palm Oil And

Deforestation Of Rainforest

percent in 2015 from last year's export volume. $^{42}$ Therefore EU becomes the main Indonesia' CPO trade export market because of the trend of trade opportunity in EU.

This case also cannot be denied by Indonesian products to penetrate the European market needs to be in line with the product standards, both quality standard and environmental production process standard. The export activity in EU for Indonesia palm oil industries meets major obstacle by EU standard, especially when the emergence of environmental issue able to make fluctuation for Indonesia's palm oil export to EU. Nevertheless, the current Indonesia's palm oil export to EU need to be analyzed since it could give the images how does the EU the current situation and standard could influence Indonesian CPO export activity. In summary, the CPO trade between Indonesia and $\mathrm{EU}$ has been conducted since the early 2000s, as EU start becomes Indonesian export main destination in the year of 2008. Both countries has gain mutual benefits from the CPO trade as Indonesia could export the palm oil to meet EU demand on vegetable oil especially after EU has policy on increasing the use of biofuels target. Therefore, the CPO trade for Indonesia is not only significant for Indonesia but also for EU.

The decline on Indonesian CPO export trend needs to be analyzed deeper on how this issue also followed by declining export volume in several EU countries. According from BPS data statistic 2016, Indonesia CPO exports in EU countries dominated by 3 major import countries, which are Netherlands, Italy and Spain. As three of major Indonesian CPO oil destination is in European countries, it is

\footnotetext{
${ }^{42}$ Widodo, T. and Widyaningtyas, D. (n.d). "Analisis Pangsa Pasar dan Daya Saing CPO Indonesia di Uni Eropa”. Univeristas Gadjah Mada Journal.
}

importance to analyze from the total volume by country destination.

Mostly the trends Indonesia exports from 2015 to 2016 on palm oil products to European countries meet the decline. ${ }^{43}$ The decline occurred in several countries include Netherlands, Denmark, Italy, Belgium and others. Meanwhile United Kingdom and rest of the countries seems fluctuant. Therefore, the data shows declining on main Indonesia's CPO market export destination in EU such as Netherland and Italy. it also brings the impact indirectly to declining on products export value.

\section{Indonesian Government Strategies in Facing EU Parliament Resolution on Palm Oil and Deforestation of Rainforest 2017}

Indonesian government strategy to responds the issue is important as it includes on the economic diplomacy practices. Economic diplomacy as well as diplomacy in general as considered as a component of foreign policy or the country's international activity to define the goals and benefits through economic diplomacy forms. ${ }^{44}$ Economic diplomacy involves a wide variety of activities and expression; in this case the writer will use the diplomatic communication that called as "démarche action" to analyze Indonesian government action on responding EU Resolution. According to Rafail Walangitan, Minister Counselor of Indonesian Ministry of Foreign Affairs, "Indonesian government action to respond the issue is called as démarche action and

\footnotetext{
${ }^{43}$ ITC Statistic. "Indonesia CPO Export to European Countries". Retrieved from www.trademap.org

${ }^{44}$ Melissen, J., Okano-Heijmans, M., and Bergeijk, P.A.G. (2011). "Economic Diplomacy: Economic and Political Perspectives". Leidon: Boston.
} 
Bustanul Arifin, Komang Audina Permana Putri| Indonesian Government Strategies On

Obtaining Crude Palm Oil (CPO) Market Access To European Union Countries Over The EU Parliament Resolution On Palm Oil And

Deforestation Of Rainforest

it is including as one of diplomatic communication way. ${ }^{45}$

Démarche is diplomatic term which part of the overall diplomatic strategy in the first place, in this case it could as a response (Spence: Dictionary of International Relations). According to the study of diplomatic communication, demarche action is the responds action, petition or protest presented through diplomatic channel. ${ }^{46}$ Thus, Rafail Walangitan, Minister Counselor of Indonesian Ministry of Foreign Affairs, even has ever said;

"The joint move we conduct to respond EU Resolution in the context of diplomacy, we call it as démarche action or it is a joint voicing action in the case of objection letter Indonesia cooperate with seven others palm oil producing countries to respond to the EU Resolution, and then in the case of CPOPC, Indonesia cooperate with Malaysia." ${ }^{47}$

\section{Objection Letter by Palm Oil Producing Countries 2017}

Since EU concerned on the case of palm oil cultivation on deforestation with the proposal of EU draft resolution in 2016, the objection letter was created by several palm oil producing countries in order to encourage EU Member of Parliament to oppose the statements regard the current condition of palm oil related with the rising of global biofuel production from foodbased oil. On March 27, 2017 particularly before the vote for EU Parliament Resolution on Palm Oil and Deforestation of Rainforest held, several palm oil

\footnotetext{
${ }^{45}$ Walangitan, R. and Siregar, R. (2017). Interviewed by the writer of this Research.

${ }^{46}$ Harvard. "Diplomatic Communication". Retrieved from https://projects.iq.harvard.edu/files/hkscommunications-

program/files/pp_sri_kulkarni_and_yotam_goren_4 _10_17.pdf

${ }^{\overline{47}}$ Walangitan, R. and Siregar, R. (2017).

Interviewed by the writer of this Research.
}

producer countries were writing an objection letter.

The letter is aimed to European Parliament President and EU Committee of Environment, Public Health and Food Safety (ENVI). Several ambassador of palm oil producing countries in Brussels that created the letter is from the ambassador from Embassy of Costa Rica, Ecuador, Honduras, Indonesia, Malaysia, Colombia and Guatemala. Each country provides the knowledge of current condition of palm oil industry, and how the views of each representative were stated through the letter. From Indonesia, the letter was signed by Indonesia's Ambassador in Brussels, HE. Mr. Yuri O. Thamrin. ${ }^{48}$

Moreover, the purposes of the letter is to underline the reasons of palm oil producing countries object EU Resolution to ban palm oil consumption for biofuel production in Europe. Indonesia itself provides the data on why palm oil industries are important for Indonesia's economy, which palm oil industries had created more than four million jobs for smallholders (traditional farmers) and laborers. This issue also include with 12 million indirect work opportunities. Moreover, the letter also stated clearly for EU to note that currently Indonesia under President Joko Widodo still continue to regulate on peat lands restoration and ISPO Policy. ${ }^{49}$ And this becomes Indonesian government concerns to have sustainable product of palm oil.

Another point that important stated by Indonesian government on the view about the resolution is a statement of discrimination trade over CPO products. Certain statements in EU Resolution considers as biased and discriminated

\footnotetext{
${ }^{48}$ Letter from Palm Oil Producing Countries.

(March 2017). Several Palm Oil Producing

Countries Oppose the EU Resolution Letter.

Retrieved from www.fern.org

${ }^{49}$ Ibid.
} 
Bustanul Arifin, Komang Audina Permana Putri| Indonesian Government Strategies On

Obtaining Crude Palm Oil (CPO) Market Access To European Union

Countries Over The EU Parliament Resolution On Palm Oil And

Deforestation Of Rainforest

against palm oil because it might give advantages for other raw materials or vegetable oil to replace palm oil for biofuels production. ${ }^{50}$ According to Rafail Walangitan, Minister Counselor of Indonesian Ministry of Foreign Affairs, Indonesian government on joint creation of objection letter has aims to persuade, influence and encourage EU ENVI to voice out clear Indonesian government views EU Resolution as an act of togetherness with others palm oil producing countries. ${ }^{51}$

\section{Indonesian Government Responses} Through Fourth Ministerial Meeting CPOPC in $11^{\text {th }}$ April 2017

The concerns of EU Resolution that considered discriminate against palm oil product might not only experience by Indonesia, but also other palm oil producing countries. Indonesia and Malaysia on the other hand have already made the established the cooperation on palm oil industries, which also called CPOPC (Council of Palm Oil Producing Countries). This council was established in 2015, pioneered by Indonesia and Malaysia. However this council would also be open for others producing countries, such as Philippine, Colombia, Brazil or Thailand. The cooperation has aims toward the meet palm oil industry's challenges; including on cooperation on further research and development for palm oil product and coordinating to control the market prize and product quality. ${ }^{52}$

Through this council, Indonesia government used its role as one of strategy to respond the EU resolution. This issue brought to the fourth Ministerial Meeting in April 2017. Indonesia and Malaysia not

\footnotetext{
${ }^{50}$ Ibid.

${ }^{51}$ Walangitan, R. and Siregar, R. (2017).

Interviewed by the writer of this Research.

${ }^{52}$ Rival, A., Montet, D. and Pioch, D. 2016.

"Certification, Labelling and Traceabilityof Palm

Oil: Can We Build Confidence from Trustworthy

Standards?". EDP Sciences Journal Retrieved from www.ocl-journal.org
}

only discussed the progress of work under CPOPC areas, however Indonesia and Malaysia's Ministers also shared their both concerns of the Resolution that might discriminate palm oil products. Through the CPOPC fourth ministerial meeting, Indonesia and Malaysia as dominant palm oil producing countries stated clearly their views on EU Resolution, and it is relevant to be noted for the EU policy maker to consider their disagreements before the EU take further on legal framework to ban palm oil uses for biofuels production.

The fourth Ministerial Meeting of CPOPC on discussing the issue of palm oil and deforestation was not exclusively aimed to discuss the issue only, however the meeting was already been schedule even before the EU Resolution had passed in $4^{\text {th }}$ April $2017 .{ }^{53}$ However the momentum of EU Resolution that occurred on the same month or just several days before the meeting, as both countries Indonesia and Malaysia disagree with the EU initiative brought to the strategy to respond the issue. ${ }^{54}$ Disappointment of both Ministerial underlines several statements that relatively similar with the objection letter and official statement by Indonesian Ministry of Foreign Affairs that has already explained on the above paragraphs.

The meeting underlines disappointment arguments toward; the encouragement to use the single certification, ignoring to have certification for other oil crops, asserts that global palm oil production breach for other social issues, and the EU Commission study 2013 which not in line with the EU Resolution statements. ${ }^{55}$ Those statements underlines in the Joint Communiqué press release. Moreover, The Executive Director

\footnotetext{
${ }^{53}$ Walangitan, R. and Siregar, R. (2017).

Interviewed by the writer of this Research.

${ }^{54}$ Ibid.

${ }^{55}$ Indonesian Ministry of Foreign Affairs Press

Release. (April 2017). "Fourth Ministerial

Meeting”. Joint Communiqué CPOPC. Retrieved from www.kemlu.go.id
} 
Bustanul Arifin, Komang Audina Permana Putri| Indonesian Government Strategies On

Obtaining Crude Palm Oil (CPO) Market Access To European Union

Countries Over The EU Parliament Resolution On Palm Oil And

Deforestation Of Rainforest

of CPOPC, Mahendra Siregar has ever stated that the initiative or the EU Resolution has "used as the guise of protectionism for the European rapeseed producers and the downstream industries such as EU biofuel". ${ }^{56} \mathrm{He}$ also emphasized that compared with vegetable oils, palm oil is the only sustainable one and without palm oil, the land conservation in the future will take much larger, especially with the current high global demand for vegetable oil use. Moreover, it is because the other vegetable oil will need more land conservation to yields. The press release also noted for the future issue with EU regarding palm oil, Indonesia with CPOPC members will work together in order to ensure Sustainable palm oil by ISPO and MSPO.

Hence, Rosmawati Siregar Secretary III of Indonesian Ministry of Foreign Affairs ever stated: "after the EU Resolution, CPOPC did not struggle to tackle the issue, however we responded the issue because there are arguments in EU Resolution which not clearly mention based on the current condition, and we concern about this issue actually to anticipate the long-term risk that could impact toward the palm oil consumption trend. It is because one of CPOPC goal is to gain the better palm oil market access or opportunities". 57 It is relevant to note that the role of CPOPC before and after the EU Resolution is actually the same, which is to keep strengthening market access for palm oil industries and campaigning the sustainable palm oil products as to maintain the quality of sustainable product.

\section{Bilateral Diplomacy on Campaigning CPO Fair Trade in 2017}

\footnotetext{
${ }^{56}$ Indonesian Ministry of Foreign Affairs Official News. (2017). "Indonesia's Assertion that Palm Oil Plays a Significant Role in Achieving SDGs".

Kemlu News. Retrieved from www.kemlu.go.id

${ }^{57}$ Walangitan, R. and Siregar, R. (2017).

Interviewed by the writer of this Research.
}

Diplomatic practice is relevant and considered as national power according to International relation study. The main instrument of diplomatic practices is negotiation. $^{58}$ As negotiation can be including formal or informal setting at any level negotiation such as bilateral form, Indonesian government's strategy after stating the objection is to conduct several informal diplomatic approaches to European countries, such as Italy and Belgium. The diplomatic visit by Indonesian Minister of Foreign Affairs conducted right after the issue of EU Resolution passed with major vote by EU Parliament. Minister of Indonesian Foreign Affairs conducted diplomatic visit and asserted the issue of palm oil in order to gain support and campaigning CPO fair trade especially after the issue of EU Resolution on palm oil and deforestation of rainforest.

Fair trade by it means for this case according to Rosmawati Siregar Secretary III of Indonesian Ministry of Foreign Affairs is the treatment or the concerns over palm oil as one of vegetable oil for biofuels production should not be only intimidate on palm oil, however the treatment also need to be pointed to all vegetables oil as feedstock for biofuels production. $^{59}$ This brought to the Indonesian Minister of Foreign Affairs to conduct bilateral approaches with Italian and Belgium Minister of Foreign Affairs. This makes important to note that campaigning the sustainable CPO trade with ISPO by Indonesian government has been conducted even before the EU Resolution passed. And after the resolution, the underline of the issue makes the Indonesian government move to repeatedly campaign on the fair treatment issue on

\footnotetext{
${ }^{58}$ Fendrick, R.J. (2012). "Diplomacy as an Instrument of National Power”. Chapter 13. p.g. 181

${ }^{59}$ Walangitan, R. and Siregar, R. (2017).

Interviewed by the writer of this Research.
} 
Bustanul Arifin, Komang Audina Permana Putri| Indonesian Government Strategies On

Obtaining Crude Palm Oil (CPO) Market Access To European Union

Countries Over The EU Parliament Resolution On Palm Oil And

Deforestation Of Rainforest

$\mathrm{CPO}$ product more often such as the Minister of Foreign Affairs bilateral visit with several European countries including Italy and Belgium. ${ }^{60}$

a. Indonesian Minister of Foreign Affairs met with Minister of Foreign Affairs of Belgium and Vice President of the European Commission for Foreign Relations and Security Policy in Brussels.

Indonesian Minister of Foreign Affairs Retno Marsudi has had a work visit with Belgium Minister of Foreign Affairs Didier Reynders and also with Vice President European Commission for Foreign Relations and Security Policy Federica Mogherini in Brussels on October $10^{\text {th }}, 2017$. Indonesian Minister of Foreign Affairs Retno Marsudi refers toward the issue on Indonesia's agriculture sector, especially for palm oil products. ${ }^{61}$ Even though the visit was not only to discuss regarding the issue, Retno Marsudi keeps underlines on the issue of negative campaigns against oil palm and it is expected to give the EU a fair treatment toward palm oil products.

Even though the bilateral diplomacy conducted by Indonesian Minister of Foreign Affairs Retno Marsudi was not only focus or bring palm oil issue as the priority topic discussion, however she stills attach the issue of palm oil and deforestation in order to campaigning the fair trade toward $\mathrm{CPO}$ products. It concludes that even before the EU Resolution passed, Indonesian government strategy on campaigning fair treatment on CPO product to tackle negative campaign has already been done. Therefore, especially after the Resolution occurred, through this meeting once again Indonesian government keep underlines the important of fair treatment toward CPO products.

\footnotetext{
${ }^{60}$ Ibid.

${ }^{61}$ Walangitan, R. and Siregar, R. (2017).

Interviewed by the writer of this Research.
}

b. Indonesian Minister of Foreign Affairs met with Italian Minister of Foreign Affairs in Rome.

According to Indonesian Ministry of Foreign Affairs Press Release, Foreign Minister Retno Marsudi also met with Italian Foreign Affairs Minister in order to strengthen bilateral relations through diplomacy and to have better economic relation especially to discuss palm oil cases. This visit conducted on October $11^{\text {th }}$ 2017. Foreign Minister Retno stressed the importance of "fair treatment" and prevents discriminatory actions against oil palm Indonesia. ${ }^{62}$ As Italia is a major importer country for Indonesia's CPO products, Foreign Minister Retno also mentions an appreciation. She stated that she gives an appreciation to the Italian Government as one of the largest importers of Indonesian palm oil that supports the palm oil industry in the country. ${ }^{63}$

She also mentioned that Italy is Indonesia's largest export destination for crude palm oil (CPO) in EU expected and supposed not to be influenced by the EU Resolution, which has not becomes EU legal policy to ban palm oil uses for biofuels production. ${ }^{64}$ Moreover, regarding the issue of EU Resolution, Indonesian Minister of Foreign Affairs also gave an overview to Italian Minister of Foreign Affairs Alfano that the Indonesian palm oil industry is considered as the Government's attention because it involves the lives of about 20 million Indonesians. ${ }^{65}$ It means that Foreign Minister Retno underlines to encourage fair treatment toward $\mathrm{CPO}$

\footnotetext{
${ }^{62}$ Indonesian Ministry of Foreign Affairs News. (October 2017). "Indonesia-Italia Intensifkan Hubungan Bilateral di Berbagai Bidang”. Kemlu News. Retrieved from www.kemlu.go.id

${ }^{63}$ Ibid.

${ }^{64}$ Ibid.

${ }^{65}$ Indonesian Ministry of Foreign Affairs News. (October 2017). "Indonesia-Italia Intensifkan Hubungan Bilateral di Berbagai Bidang”. Kemlu News. Retrieved from www.kemlu.go.id
} 
Bustanul Arifin, Komang Audina Permana Putri| Indonesian Government Strategies On

Obtaining Crude Palm Oil (CPO) Market Access To European Union

Countries Over The EU Parliament Resolution On Palm Oil And

Deforestation Of Rainforest

products to Foreign Minister Alfano. In that meeting, Indonesia also discussed some other issues as well.

\section{Negotiating Palm Oil Issue through Indonesia EU-CEPA}

Another Indonesian government strategy is to conduct officially formal discussion through the economic cooperation commitment between Indonesia and EU has, and in this case will be Indonesia-EU Comprehensive Economic Partnership Agreement (IEU CEPA). Throughout the agreement, the diplomatic practices regard with the issue on sustainable palm oil would clearly defined in the negotiation. Indonesia and European Union officially launched CEPA Negotiation in 2016 and the issue of palm oil and deforestation becomes the one of the topic on "Trade and Sustainable Development or TSD" in IEU-CEPA $\left(3^{\text {rd }}\right.$ Round Negotiation) on September 2017. The analytical framework of economic diplomacy on external negotiation consists by three angles that analyzed to explain the diplomacy processes are; the economic tools as what, diplomacy process as how, and theatre as where.

CEPA has a general principle of comprehensive cooperation, mutual respect, the spirit of development, equal sovereignty, and mutual benefit for both parties. $^{66}$ This becomes a tangible manifestation of the spirit of partnership between the two parties who make an agreement later will provides mutual benefits. Therefore, since the agreement of CEPA, any of trade barriers or challenges faced either by EU or Indonesia are considered relevant to discuss through CEPA. Moreover, for Indonesia, EU is the fourth largest trade partner. For the highest export commodity is agricultural product. Meanwhile for EU, Indonesia is the fifth

\footnotetext{
${ }^{66}$ Ibid.
}

largest trade partner in the region of South East Asia. $^{67}$

EU Parliament Resolution Issue on IEU CEPA $\left(3^{\text {rd }}\right.$ Round Negotiation) in September 2017

In line with the scoping paper on IEU-CEPA, which to discourage the unfair and discrimination trade, the negotiation on third round of IEU-CEPA apparently insert palm oil issue as the one of the topic discussion. The negotiation was held from 11-15 September 2017 in Brussels. ${ }^{6}$ The negotiation on palm oil issue consists in the topic of Trade and Sustainability Development (TSD). In the Indonesia-EU CEPA negotiations, it is mentioned that the scope of discussion of the TSD chapter in IEU CEPA will be directed at strengthening the commitment and cooperation of both parties on sustainable development in terms of economic and social development, and environmental protection. ${ }^{69}$ The key point that discussed on negotiation is specific exchanging information and views on Indonesia progress on pursuing ISPO certification.

Moreover, EU also expected with the IEU-CEPA negotiating process will go toward positive on mutual economic benefits. In this 3rd round, the two sides will discuss deeply the issue of palm oil at a special session in an effort to find a balanced and mutually beneficial

\footnotetext{
${ }^{67}$ Indonesia Ministry of Trade. (2016). "IndonesiaEuropean Union Officially Launches CEPA Negotiation". Press Release. Retrieved www.kemendag.go.id

${ }^{68}$ European External Action Service. (September 2017). "Report of the $3^{\text {rd }}$ round of negotiation for free trade agreement between EU and Indonesia". EEAS Report. Retrieved from https://eeas.europa.eu/delegations/indonesia_fr/3311 $1 / \mathrm{EU}-$

Indonesia $\% 20$ CEPA: $\% 203$ rd $\% 20$ round $\% 20$ of $\% 20$ n egotiations

${ }^{69}$ Indonesia Global Justice. (2017). "Isu Pembangunan Berkelanjutan dan Sawit Indonesia". Indonesia Global Justice". Press Release. Retrieved from www.igj.org
} 
Bustanul Arifin, Komang Audina Permana Putri| Indonesian Government Strategies On

Obtaining Crude Palm Oil (CPO) Market Access To European Union

Countries Over The EU Parliament Resolution On Palm Oil And

Deforestation Of Rainforest

solution. ${ }^{70}$ The TSD session discussed on palm oil issue with these three main statements:

a. According to Rosmawati Siregar, Secretary III of Indonesian Ministry of Foreign Affairs through dialogue in IEU-CEPA Indonesian government discuss more toward the harmonization on EU standard on sustainable palm oil and Indonesian government presented the progress of ISPO as Indonesian palm oil standard of sustainable certification. $^{71}$

b. Indonesian government expressed with the on-going work to enhance Indonesian Sustainable Palm Oil (ISPO) certification system. On the goals of Indonesian government to gain more access market on sustainable label products, therefore the "sustainable" label in Indonesian palm oil products becomes opportunity for Indonesia to encourage on opening more market access for Indonesian CPO products in the EU market. ${ }^{72}$

c. Indonesian government also encourages EU to have consistent treatment over palm oil. This issue is due to the EU is often inconsistent in treating illegal goods entering the market from other countries, including palm oil product. $^{73}$

Therefore, Indonesia will encourage the EU to have better knowledge about

\footnotetext{
${ }^{70}$ Indonesia Ministry of Trade. (2017). "Indonesia Dorong Finalisasi Kerangka Perundingan Akses Pasar dalam Perundingan Putaran ke-3 IndonesiaEU CEPA". Press Release. Retrieved from www.kemendag.go.id

${ }^{71}$ Walangitan, R. and Siregar, R. (2017). Interviewed by the writer of this Research.

${ }^{72}$ Indonesia Global Justice. (2017). "Isu

Pembangunan Berkelanjutan dan Sawit Indonesia". Indonesia Global Justice". Press Release. Retrieved from www.igj.org

${ }^{73}$ Ibid.
}

Indonesian efforts. For the harmonizing the ISPO certification with EU standard, Indonesian government questions more about the current EU's sustainable requirements especially for $\mathrm{CPO}$ products. This exchange information, it would expect the ISPO would meet the EU requirement that still on the progress of maximum realization in the field.

\section{Conclusion}

Finally, the objectives of these strategies used by Indonesian government are to sustain palm oil market access to European countries, to maintain Indonesian $\mathrm{CPO}$ export volume toward and also to prevent long-term risk on weakening of global palm oil consumption trend. Indonesia is a highest palm oil production and EU becomes Indonesia's third largest export palm oil countries destination after India and China. Therefore, trade relations especially on palm oil between both sides is significant due to the large position of EU for Indonesian CPO market access.

Back to the main objective of this research to analyze Indonesian government strategies to face EU Resolution, the writer summarized that there are four main strategies, which conducted by Indonesian government to respond and negotiate the issue. Four main strategies are Indonesia government effort by making a joint of creation of objection letter, by responding over the issue through CPOPC role, by campaigning the fair trade of CPO products through bilateral approaches by Indonesian Minister of Foreign Affairs, and lastly by negotiating with EU through Indonesia EU CEPA.

The key point for those Indonesian Government strategies through diplomatic approaches is to state a clear objection and to emphasize more about the current ongoing progress of ISPO policy. In addition, others palm oil producing countries also put their concern, which reveals that Indonesia is not the only country that struggle with 
Bustanul Arifin, Komang Audina Permana Putri| Indonesian Government Strategies On

Obtaining Crude Palm Oil (CPO) Market Access To European Union Countries Over The EU Parliament Resolution On Palm Oil And

Deforestation Of Rainforest

the issue. Therefore, on Indonesian strategies through joint action of the creation on objection letter with others palm oil producing countries technically will strengthen the collective view on the development of sustainable CPO products with the cooperation strategy in order to gain the same goal, which is to maintain the CPO trade market access. Especially, these strategies on diplomatic practices could have opportunity to sustain mutual trade relation between EU and Indonesia, however palm oil issue is still very critical for Indonesian government national interest. 
Bustanul Arifin, Komang Audina Permana Putri | Indonesian Government Strategies On Obtaining Crude Palm Oil (CPO) Market Access To European Union Countries Over The EU Parliament Resolution On Palm Oil And Deforestation Of Rainforest

\section{REFERENCES}

ASEAN-EU Press Release. Co-chairs' Press Release. Retrieved from http://www.mfa.go.th/asean/contents/files/news-20170707-120753-320915.pdf

Agustira, M. A., and Ranola, R. F. (2017). Economic Gains and Losses of Sustainable Smallholders Oil Palm". International Invention Journal of Art and Science: university of Philippine. Retrieve from https://internationalinventjournals.org.

Bambang Dradjat, (n.d). Overcoming Black Campaign on Palm Oil and Developing Future Strategy.Bayne N., Woolcock S. (2010). 2nd edition. The New Economic Diplomacy. Decision-making and Negotiation in International Economic Relations. Surey (UK): Ashgate Publishing Limited, ISBN 978-0-7456-7048-3, p. 391

Book II Report on Ministry of Foreign Affairs Indonesia Year 2016. (2016). "Laporan Kinerja Kemenlu Tahun 2016". Retrieved from www.kemlu.go.id

Borisova, Y. V. (2013). "Diplomatic Correspondence". The University of World Economy and Diplomacy Journal. p.g. 29

BPS. (2016). "Statistik Kelapa Sawit Indonesia di Tahun 2016". Retrieved from www.bps.go.id

Byerlee, D., Falcon, W.P., and Naylor, R. L. (2017). The Tropical Oil Crop Revolution. New York: Oxford University Press.

Daemeter. (2015). "Indonesia's Evolving Governance Framework for Palm Oil". Daemeter Consulting Report. Retrieved form www.daemeter.org

Daemeter. (2015). "Overview of Indonesian Oil Palm Smallholder Farmers". Daemeter Consulting Report. Retrieved from www.daemeter.org

Dharmawan, D. and Sarianti, T. (2015). Indonesia's Crude Palm Oil (CPO) Against Black Campaign.

Ernst and Young Study. (2011). Biofuels and Indirect Land Use Change: The Case For Mitigation". Ernst and Young Study. Retrieved from https://www.iucn.org/sites/dev/files/content/documents/biofuels_and_indirect_lan d_use_change.pdf

EU Study (2013). "Impact of EU Consumption on Deforestation". European Commision Technical Report- 063. Retrieved from http://ec.europa.eu/environment/forests/pdf/1.\%20Report\%20analysis\%20of\%20i mpact.pdf

European Commission Report. (2017). "Renewable Energy Progress Report". Retrieved from https://ec.europa.eu/transparency/regdoc/rep/1/2017/EN/COM2017-57-F1-EN-MAIN PART-1.PDF

European External Action Service. (September 2017). "Report of the 3rd round of negotiation for free trade agreement between EU and Indonesia". EEAS Report. Retrieved from https://eeas.europa.eu/delegations/indonesia_fr/33111/EUIndonesia\%20CEPA:\%203rd\%20round\%20of\%20negotiations

European External Action Service (EEAS). "Trade in Goods". Retrieved from http://eeas.europa.eu/delegations/indonesia/eu_indonesia/trade_relation/trade_flow s/index_en.htm.

EU Inherit. (n.d). "Palm Oil: Reliable Biofuel or Environmental Nightmare?". 
Bustanul Arifin, Komang Audina Permana Putri | Indonesian Government Strategies On

Obtaining Crude Palm Oil (CPO) Market Access To European Union Countries Over The EU Parliament Resolution On Palm Oil And

Deforestation Of Rainforest

Retrieved from www.inherit.eu

EU Parliament News. (April 2017). "MEPs call for clampdown on imports of unsustainable palm oil and use in biofuels". Retrieved from www.europarl.europa.eu.

European Parliament Resolution. (4 April 2017). Texts adopted, P8_TA(2017)0098.

European Parliament. Procedure File: 2016/2222(INI). Retrieved from www.europarl.europa.eu

Fendrick, Reed J. (2012). "Diplomacy as an Instrument of National Power." Chapter 13 in Bartholomees, J. Boone, Jr., ed., U.S. Army War College Guide to National Security Issues.

FAO (Food, Agriculture Organization) Report. Global Resources Assessment 2010. Retrieved from www.fao.org.

Forum Kelapa Sawit Berkelanjutan Indonesia. (2017). Rencana Aksi Nasional Kelapa Sawit Berkelanjutan. Draft Report. Retrieved from www.foksbi.id.

GAPKI. (2017). "Sertifikasi Berkelanjutan Hanya pada Sawit”. GAPKI News Junuary 2017. Retrieved from www.gapki.id

Harvard. (2017). "Diplomatic Communication". Harvard Journal. Retrieved from https://projects.iq.harvard.edu/files/hks-communicationsprogram/files/pp_sri_kulkarni_and_yotam_goren_4_10_17.pdf

Indonesia Global Justice Press Release. (2017). "Isu Pembangunan Berkelanjutan dan Sawit Indonesia". Retrieved from www.igj.org

Indonesia Investments Article. (n.d). Minyak Kelapa Sawit. Retrieved from www.indonesia- investment.com.

Indonesian Ministry of Agriculture. ISPO Lampiran V. Retrieved from http://www.ispoorg.or.id/images/pearturan/LAMPIRAN\%20V\%20PC\%20Plasma.pdf

Indonesia Ministry of Trade Press Release. (2016). "Indonesia-European Union Officially Launches CEPA Negotiation". Retrieved www.kemendag.go.id

Indonesia Ministry of Trade Press Release. (2017). "Indonesia Dorong Finalisasi Kerangka Perundingan Akses Pasar dalam Perundingan Putaran ke-3 IndonesiaEU CEPA". Retrieved from www.kemendag.go.id

Indonesian Ministry of Trade Report. (2013). Analysis of Indonesia's strategies to Increase Crude Palm Oil Production. Retrieved from http://bppp.kemendag.go.id

Indonesian Ministry of Foreign Affairs (April 2017). Joint Communiqué: Fourth Ministerial Meeting Council of Palm Oil Production Country. Indonesia MOFA Document.

Indonesian Ministry of Foreign Affairs News. (2017). "Indonesia's Assertion that Palm Oil Plays a Significant Role in Achieving SDGs". Kemlu News. Retrieved from www.kemlu.go.id

Indonesian Ministry of Foreign Affairs News. (October 2017). "Indonesia-Italia Intensifkan Hubungan Bilateral di Berbagai Bidang". Kemlu News. Retrieved from www.kemlu.go.id.

Indonesian Ministry of Foreign Affairs News. (October 2017). "Menlu RI Retno Bahas Masalah Kelapa Sawit di Belgia". Kemlu News. Retrieved from www.kemlu.go.id. 
Bustanul Arifin, Komang Audina Permana Putri | Indonesian Government Strategies On Obtaining Crude Palm Oil (CPO) Market Access To European Union Countries Over The EU Parliament Resolution On Palm Oil And Deforestation Of Rainforest

Indonesian Ministry of Foreign Affairs News. (n.d.) "Hubungan Ri-Uni Eropa Di Bidang Politik Dan Keamanan". Retrieved from https://www.kemlu.go.id/id/kebijakan/kerjasama-regional/Pages/Uni-Eropa.aspx

Indonesian Ministry of Foreign Affairs Press Release. "Di ASEAN-EU Meeting, Indonesia Sesalkan Resolusi Kelapa Sawit Uni Eropa”. Retrieved from www.kemlu.go.id.

Indonesian Ministry of Foreign Affairs Press Release. (2017). "Tanggapan Atas Resolusi Parlemen Eropa Tentang Minyak Sawit”. Retrieved from www.kemlu.go.id.

Indonesian Ministry of Foreign Affairs Press Release. (October 2017). Menlu Retno Berbagi Keberagaman RI dengan Menlu Belgia". Retrived form www.kemlu.go.id

ITC Trade Map. "Indonesia CPO Export to European Countries". Retrieved from www.trademap.org.

Katadata Research. (2016). "Volume Ekspor Minyak Sawit ke 10 Negar Tujuan Utama". Retrieved from www.databoks.katadata.co.id

Katadata Research. (2017). “ Berapa Produksi dan Ekpor Minyak Sawit Indonesia?”. Retrieved from https://databoks.katadata.co.id

Kothari, C.R (2004) Research Methodology, Methods and Techniques (Second Revised Edition). New Delhi: New Age International Ltd. p. 3

Kurnia, Jundika C, Ssachin V. Jangam, and others. (2016). Biofuel Research Journal "Advances in biofuel production from oil palm and palm oil processing wastes". Retrieved

from http://www.biofueljournal.com/article_11937_b39e801349deb76be4a15f0a1fd93e 3c.pdf.

Lane, L. (2011). "Emission Controls, Economic Growth, and Palm Oil Production". Hudson Institute Briefing Paper. Retrieved from www.hudson.org.

McCormick, J. (2014). "Understanding the European Union: A Concise Introduction Sixth Edition". Palgrave Macmillan; New York.

Melissen, J., Okano-Heijmans, M., and Bergeijk, P.A.G. (2011). "Economic Diplomacy: Economic and Political Perspectives". Leidon: Boston.

Mohd Noor, F. M., A. Gassner, A. Terheggen, and P. Dobie. (2017). Beyond sustainability criteria and principles in palm oil production: addressing consumer concerns through in setting. Ecology and Society 22(2):5. https://doi.org/10.5751/ES-09172-220205

MPOC. (2014). "Use of ILUC in EU regulation Fundamental Challenges in Science Remain Unresolved". Copenhagen Economics Report. Retrieved from www.copenhageneconomics.com

Pacini, H., Silveira, S. and Filho, A. (2013). "The European Biofuels Policy from Where and Where to?". European Energy Journal; Volume 3, Issue 1. Retrieved from http://www.diva-portal.org/smash/get/diva2:600737/fulltext01.pdf

Pahan, I. (2006). "Kelapa Sawit;Manajemen Agribisnis dari Huku Hingga Hilir (Panduan Lengkap)". Gapki; Jakarta

Pacheco, P., Gnych, S., Dermawan, A., Komarudin, H. and Okarda, B. 2017. Tha Palm Oil Global Value Chain: Implication of Economic Growth, Social and Environmental Sustainability. Working Paper 220. Bogor, Indonesia: CIFOR. 
Bustanul Arifin, Komang Audina Permana Putri | Indonesian Government Strategies On Obtaining Crude Palm Oil (CPO) Market Access To European Union Countries Over The EU Parliament Resolution On Palm Oil And Deforestation Of Rainforest

PHYS Article. (June, 2017). "No, Palm Oil is Not Responsible for $40 \%$ of Global Deforestation". PHYS Article. Retrieved from https://phys.org/news/2017-06palm-oil- responsible-global-deforestation.html.

Rana, S. K. (2002). "Bilateral Diplomacy". Mediterranean Academy of Diplomatic Studies; University of Malta

Ranathunga, C. (2017). "Indonesian and Malaysian Palm Oil Industry at Critical Crossroads, Given EU Resolution to Ban Palm Oil in Biofuels by 2020". Global Research and Analysis Team.

Renewable Energy Association. "Renewable Transport Fuels". Retrieved from www.re-a.net.

Rival, A., Montet, D. and Pioch, D. (2016). "Certification, Labelling and Traceabilityof Palm Oil: Can We Build Confidence from Trustworthy Standards?". EDP Sciences Journal Retrieved from www.ocl-journal.org.

R. Vasuthewan. (2017). "EU Parliament's Resolution to Ban Palm Oil by 2020?". ISCC Report. Retrieved from www.iscc-system.org

Sawit Indonesia. (2014). "Menjaga Pasar CPO Eropa". Sawit Indonesia News. Retrieved from www.sawitindonesia.com

Sawit Indonesia. 2017. "Resolusi Uni Eropa Terkait Pelarangan Sawit Melukai Kedaulatan Indoneia". Retrieved from www.sawitindonesia.com

Spence, J. E. (n.d). Dictionary of International Relations. Penguin Reference.

Statement Letter from NGOs to European Parliament. (April 2017). Undersigned Organization Letter. Retrieved from www.fern.org.

Statista. "Palm Oil consumption in EU from 2011 to 2016 (in 1000 metric tons). Retrieved form www.statista.com

Sundram, K., (2017). “The EU's Palm Oil and Deforestation Resolution". Retrieved from www.palmoilhealth.org.

T\&E Study (2016). Cars and Truck Burn Almost Half of Palm Oil Used in Europe. Retrieved from www.transportenvironemnt.org.

Velde, Bruno Vander. 2017. Europe Moves to Restrict Import of Unsustainable Palm Oil.

Widodo, T. and Widyaningtyas, D. (2017). "Analisis Pangsa Pasar dan Daya Saing CPO Indonesia di Uni Eropa". Univeristas Gadjah Mada Journal.

Wijatno, S and Gunadi, A. (2014). "Free Trade: in International Trade Law Perspective”. PT. Grasindo; Jakarta. 